\title{
アセトンブタノール醱酵紐菌によるビタミン $\mathrm{B}_{2}$ の合成（第 4 報）
}

\author{
玉羁乘中に存与る生長素の抽出 \\ 今 北和民 (京都大学旺学部) \\ 昭和 30 年 3 月 4 日受理
}

On the Formation of Riboflavin by Acetone-Butanol Fermentation Bacteria.

Part 4. Extraction of Growth Factors from Maize.

By Kazutami IMAI (Faculty of Agriculture, Univ. of Kyoto)

\section{I. 緒}

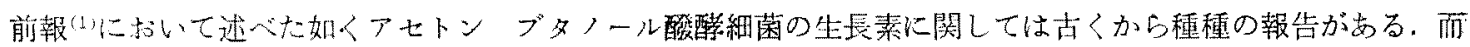
して著者は該菌によるり六フラビンの合成を破究寸る上炕グルコース, アスパラギン,アルギニン, phytic acid:

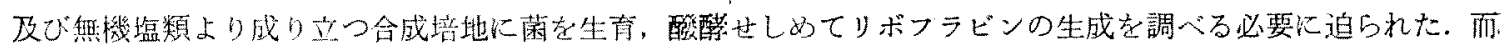

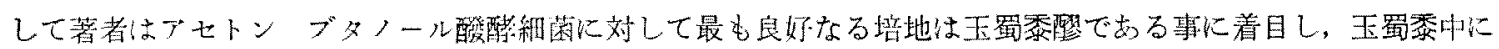

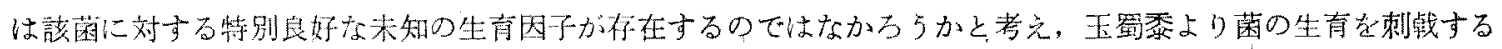

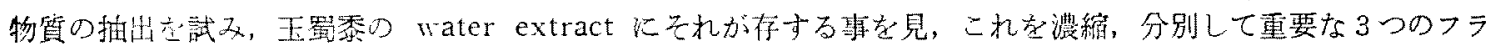

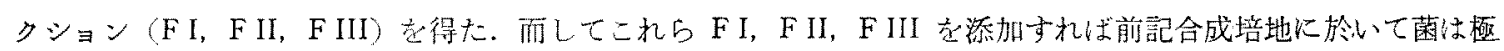

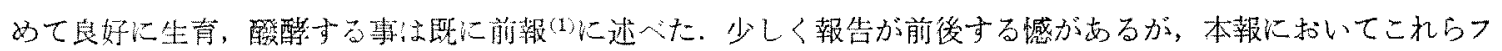
ラクションの抽出, 並しに分別澧縮について述べる.

\section{II. 実 験 の 部}

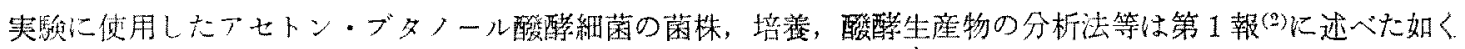
である。

\section{I. 生長素の抽出}

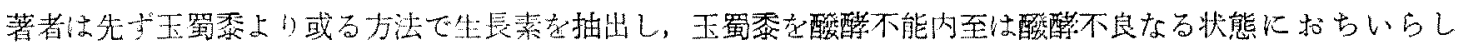

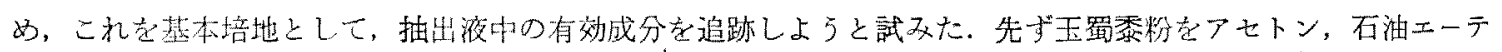
ル, ベンゾール, プロハノール, 酳酸メチル, 醋酸エチル, 及びエタ〉ール等で抽出した。 この場合プロパノー

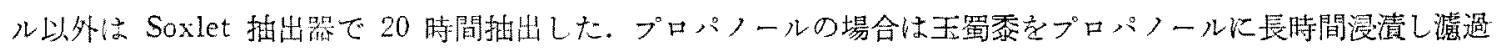

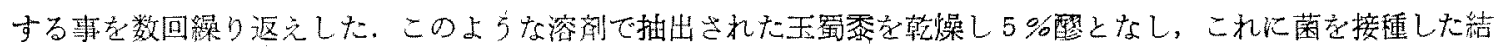
果は Table 1 に示した如くいずれも良く酸酵し，無処理のむのと全く差が認めらなかつた，然しェタノールて 抽出されたものにあっては酸酩がやゃ不良となる事が認奶られた。

Table 1. Fermentation on Maize Mash Extracted with Various Solvents.

\begin{tabular}{|c|c|c|c|c|c|c|c|c|c|c|c|c|c|c|c|}
\hline \multirow{5}{*}{ 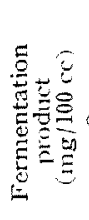 } & Acetone & 320 & 354 & 321 & 344 & 344 & 309 & 313 & 300 & 313 & 309 & 337 & 311 & 286 & 232 \\
\hline & Butanol & 650 & 688 & 642 & 676 & 672 & 658 & 642 & 608 & 648 & 658 & 664 & 640 & 514 & 400 \\
\hline & Ethanol & 100 & 81 & 73 & 103 & 84 & 52 & 68 & 61 & 63 & 94 & 86 & 88 & 82 & 40 \\
\hline & Butyric acid & 46 & 65 & 114 & 68 & 35 & 76 & 86 & 68 & 68 & 77 & 77 & 36 & 86 & 68 \\
\hline & Acetic acid & 142 & 106 & 87 & 111 & 111 & 113 & 105 & 119 & 101 & 98 & 97 & 155 & 105 & 118 \\
\hline \multicolumn{2}{|c|}{ Starch consumed $\left(0_{0}\right)$} & 90 & 91 & 94 & 88 & 86 & 86 & 88 & 89 & 89 & 85 & 86 & 89 & - & 78 \\
\hline \multicolumn{2}{|c|}{ Extraction } & none & & & $\begin{array}{l}\text { jetro- } \\
\text { leum } \\
\text { ther }\end{array}$ & & & & & & & & & & nol \\
\hline
\end{tabular}

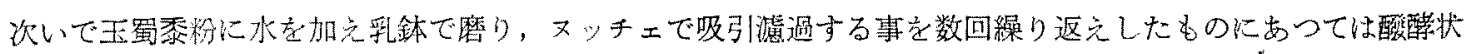
沉が相当昰くなる. 同样つ操作志水の代りに $5 \% \mathrm{HCl}, 10 \% \mathrm{H}_{2} \mathrm{SO}_{4}$ 或いは $1 N$ 醌酸を用いて行い, 後水で洗つ たものは酸酝が著るしく悪くなり，殊に $1 N$ 醋酸を用いた場合には殆儿ど酸醋しなくなる事を知つた。これら の結果は Table 2 に示した如くでかる.

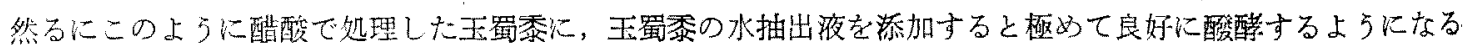

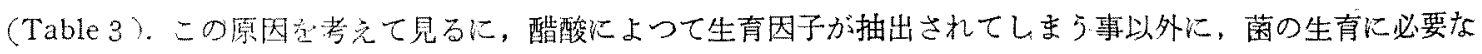


Table 2. Fermentation on Maize Mash Extracted with Water or Acids.

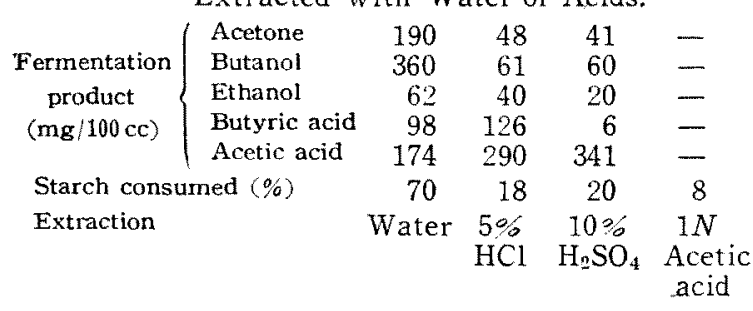

Table 3. Fermentation on Acid Treated Maize Mash.

\begin{tabular}{|c|c|c|c|c|}
\hline \multirow{3}{*}{$\begin{array}{l}\text { Fermentation } \\
\text { product }\end{array}$} & Acetone & 318 & 134 & 175 \\
\hline & Butanol & 640 & 168 & 300 \\
\hline & Ethanol & 76 & 112 & 68 \\
\hline \multirow[t]{2}{*}{$(\mathrm{mg} / 100 \mathrm{cc})$} & Butyric & acid 73 & 12 & 127 \\
\hline & Acetic : & acid 145 & 292 & 255 \\
\hline \multicolumn{2}{|c|}{ Starch consumed $(\%)$} & 85 & 30 & 52 \\
\hline Addition & & $\begin{array}{l}\text { Water ext. } \\
\text { of maize }\end{array}$ & $\begin{array}{l}\text { SPEAKMAN } \\
\text { Salts }\end{array}$ & $\begin{array}{l}\text { M/30 Phos- } \\
\text { phate buffer } \\
\text { (pH } 6.4 \text { ) }\end{array}$ \\
\hline
\end{tabular}

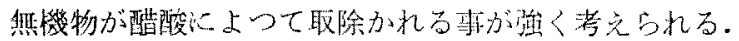

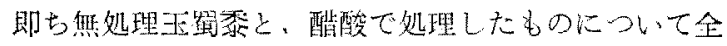

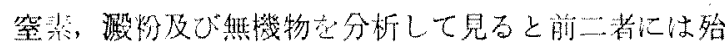

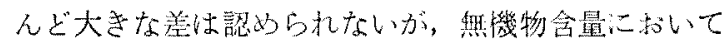

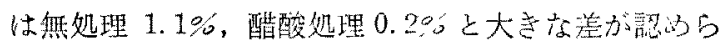

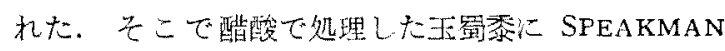
塩類支添加して見た。この塩類は SPEAKMAN(3)の 提唱したものでアセトン・ブタノール酸醇細菌にとつ

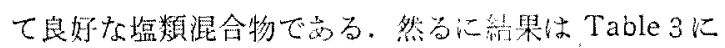
示した如く，やや酸醉して来るがブタノールの生痤異

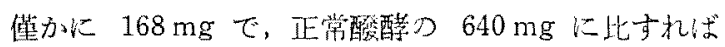

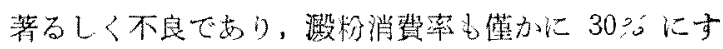
ぎからた. 又 buffer action の炬方原因とたつて

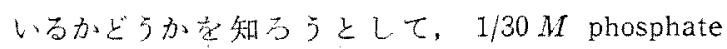

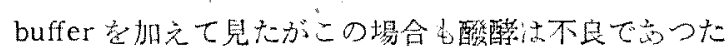

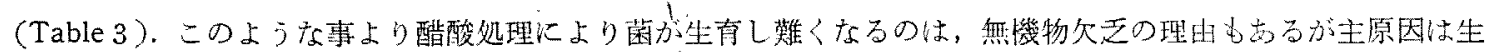
育因子の抽出である之推諭出来る。

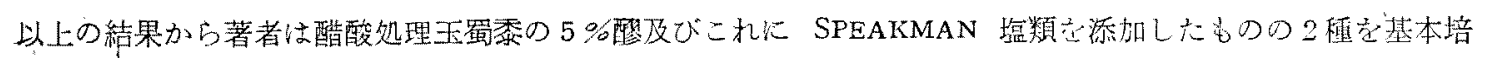

Table 4. Extraction Method of Growth Promoting Substances from Maize.

Ground maize [3 kg] -extracted with water

Residue

Filtrate (b) Ppt (a) $[6.6 \mathrm{~g}]$ - concentrated into $500 \mathrm{cc}$ and added the same volume of acetone

Filtrate (d) 'Ppt (c) [25 g] - evaporated into syrup and treated with ethanol

Ethanol solution (g) - chasing ethanol, acidified with $\mathrm{H}_{2}$ $\mathrm{SO}$ and extracted with ether

Water layer Ether layer (h) -chasing ether
and treated and treated added ethano trate (j) Ppt (i) $[0.35 \mathrm{~g}]$

Filtrate (j) Ppt (i) $[0.35 \mathrm{~g}]$ absolute alcohol

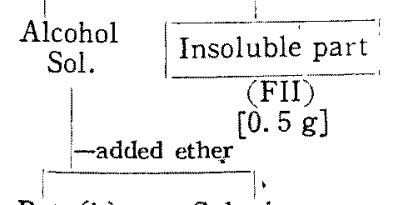

Ppt (k) Solution -chasing solvent, dissolved in $5 \mathrm{cc}$ of water

Solution (FI) $[5 \mathrm{cc}]$
Water ext. $[4 l]$ -heated on water bath for half an hour, filter

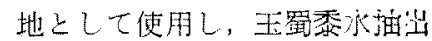
液中心生是素迫跡することと した。

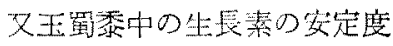

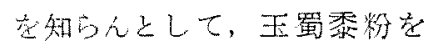
$N / 50 \mathrm{NaOH}, N / 20 \mathrm{NaOH}$ 及び $\mathrm{N} / 10 \mathrm{HNO}_{3}$ で湯答上で 2 時間 加器し, 得 $\mathrm{HCl}$ 及び $\mathrm{NaOH}$

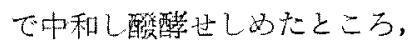

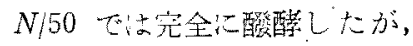

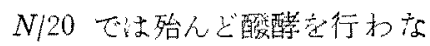
か⿰た。 これに反し $N / 10 \mathrm{HNO}_{3}$ で処理したものはブタノール

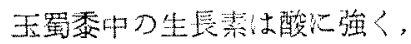

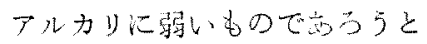
推諭される。

\section{II. 生長素の分别濃縮}

Cathode Middle Anode Chamber (1) Chamber Chamber (m) (n) -neutralized with $\mathrm{H}_{2} \mathrm{SO}_{4}$, condensed and added acetone

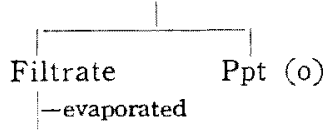

Condensed

Solution

(FIII) $[10 \mathrm{cc}]$

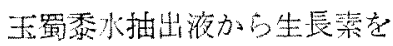
分別浀縮する方法は Table 4 亿 手した如くである。 今この Table 4 に徒つてての告長掏を

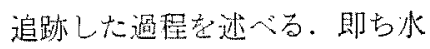

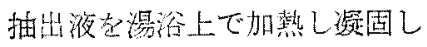

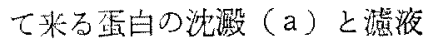
$127 \mathrm{mg} / 100 \mathrm{cc}$ 索生成したつで, （b）上に分十る。醰酸処理玉蜀 番に（a）在添加（以下各物質 
○添加舅は総七水抽出滩在基

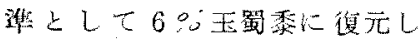

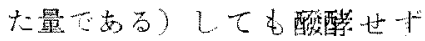
SPEAKMAN 程之（a）党作用

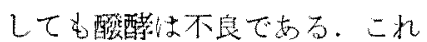
に反し (b) 坴添加したものはこ れだけで管全に酸醋する。この

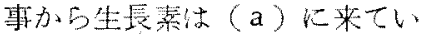

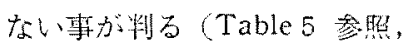

以下同様)。次いて二の溜液茫 濃維し等量のア七トンを加无て

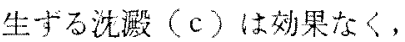

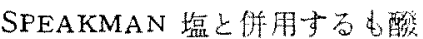

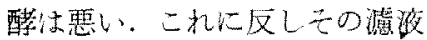

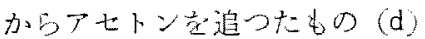

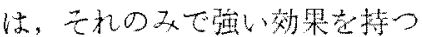
てい夕. 次起に二の (d) 等シ

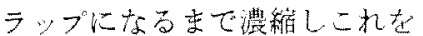
工多，一ルで処理すると㖶脂状

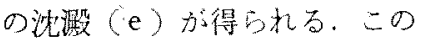

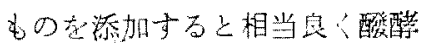
するが，これ老少量の水に溶力 し工夕ノ一几処理市る事老2回 繢り返夫したもの（f）走添加

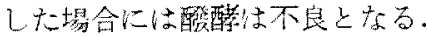
これに SPEAKMAN 塩索添加

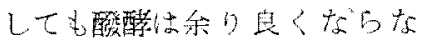

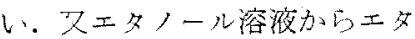

Table 5. Fermentation on Acetic Acid Treated Maize Mash under the Addition of Various Eractions Extracted from Maize, *

Addition*

(a)

(a) + Sp. salts

(b)

(c)

(c) + Sp. salts

(d)

(e)

(e) + Sp. salts (f)

(f) - - Sp. salts (g)

(g) - Sp. salts

(f) $+(\mathrm{g})$

(1) +1 h)

$(f)+(i)$

(f) $+(j)$

$(\mathrm{f})+(\mathrm{FI})$

(f) + (FII)

(f) $+(k)$

(f) + (FI) + (k)

(f) $+($ FII $)+(k)$

(f) $-(\mathrm{FI})+(\mathrm{FII})$

(f) $+(\mathrm{FI}+(\mathrm{FII})+(\mathrm{k})$

(f) $-\mid \mathrm{Fl} ;-$-ash of (FII)

ash of $(f)+(\mathrm{FI})+(\mathrm{FII})$

(FI) + - FII

$(\mathrm{FI}+\mathrm{i}-(\mathrm{FII})+(\mathrm{l})$

$(\mathrm{FI})+(\mathrm{FII})+(\mathrm{m})$

$(\mathrm{FI}+\mathrm{i}-(\mathrm{FII})-\mathrm{n})$

$(\mathrm{FI},+(\mathrm{FII})+-(1)$

(FI + - FII $)+$ Sp. salts

$(\mathrm{FI}+(\mathrm{FII})+$ ash of $(\mathrm{I})$

$(\mathrm{FI})+(\mathrm{FII})+(\mathrm{FIII})+(\mathrm{O})$

(FI) - FII $)$ - (FIII $)$-Sp.salts 356 Sp. salts $=$ SFEAKMAN's salts
Fermentation product $(\mathrm{mg} / 100 \mathrm{cc})$

\begin{tabular}{|c|c|c|c|c|}
\hline $\begin{array}{r}\text { Acetone } \\
\text { not }\end{array}$ & $\begin{array}{c}\text { Butanol } \\
\text { fermented }\end{array}$ & Ethanol & $\begin{array}{l}\text { Butyric } \\
\text { acid }\end{array}$ & $\begin{array}{l}\text { Acetic } \\
\text { acid }\end{array}$ \\
\hline 172 & $3 \geq 8$ & 50 & 6 & 283 \\
\hline \multirow{2}{*}{\multicolumn{5}{|c|}{ not fermented }} \\
\hline & & & & \\
\hline 196 & 362 & 42 & 22 & 210 \\
\hline 322 & 640 & 108 & 39 & 156 \\
\hline 300 & 522 & 66 & 45 & 141 \\
\hline 328 & 600 & 60 & 46 & 165 \\
\hline 130 & 200 & 30 & 25 & 195 \\
\hline 250 & 480 & 54 & 75 & 114 \\
\hline 200 & 340 & 46 & 53 & 173 \\
\hline 220 & 440 & 52 & 36 & 156 \\
\hline 320 & 700 & 100 & 64 & 145 \\
\hline 316 & 656 & 110 & 105 & 138 \\
\hline 234 & 410 & 62 & 18 & 240 \\
\hline 310 & 614 & 104 & 44 & 165 \\
\hline 174 & 344 & 42 & 22 & 210 \\
\hline 212 & 400 & 30 & 31 & 264 \\
\hline 200 & 410 & 80 & 44 & 225 \\
\hline 250 & 450 & 66 & 24 & 253 \\
\hline 220 & 442 & 84 & 39 & 243 \\
\hline 320 & 630 & 110 & 26 & 193 \\
\hline 313 & 620 & 100 & 35 & 208 \\
\hline 154 & 280 & 60 & 22 & 300 \\
\hline 124 & 230 & 40 & 33 & 322 \\
\hline not & fermented & & & \\
\hline $\begin{array}{l}380 \\
\text { not } \\
\text { not }\end{array}$ & $\begin{array}{l}740 \\
\text { fermented } \\
\text { fermented }\end{array}$ & 100 & 24 & 88 \\
\hline 385 & 710 & 100 & 18 & 78 \\
\hline 124 & 230 & 40 & 33 & 322 \\
\hline 120 & 178 & 28 & 30 & 300 \\
\hline 380 & 720 & 100 & 18 & 77 \\
\hline $\operatorname{ts} 356$ & 660 & 140 & 33 & 98 \\
\hline
\end{tabular}

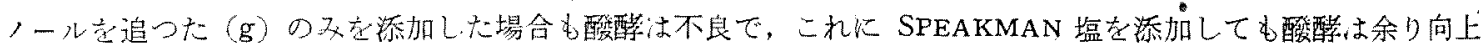

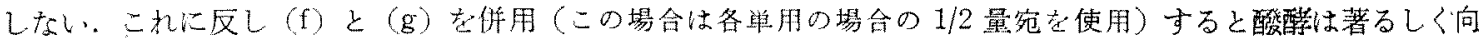
上した。故にここで生長素がこ部分に分たれる事が判つた。ついで（g）を硫酸酸性にてェーテル抽出する.

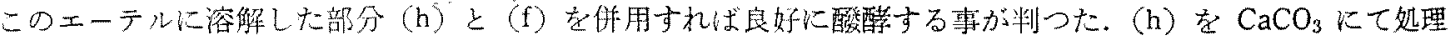

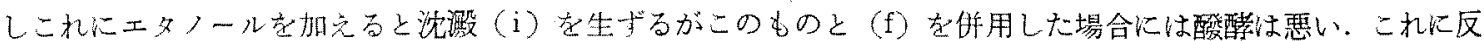

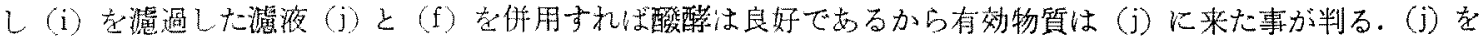

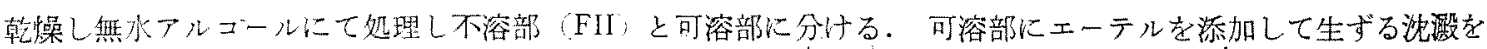
(k)とする，濾液からアルコールとエーテルを追い水 $5 \mathrm{cc}$ に溶かす この溶液を(FI)とする。このようにして

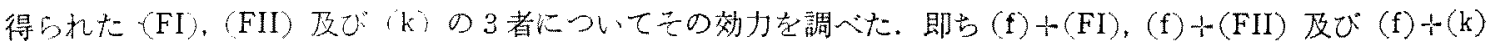

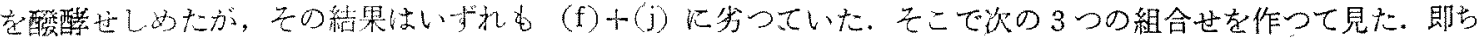
(f) $+(\mathrm{FI})+(\mathrm{k}),(\mathrm{f})+(\mathrm{FII})+(\mathrm{k}),(\mathrm{f})+(\mathrm{FI})+(\mathrm{FII}),(\mathrm{f})+(\mathrm{FI})+(\mathrm{FII})+(\mathrm{k})$. その結果，前 2 者は後 2 者に

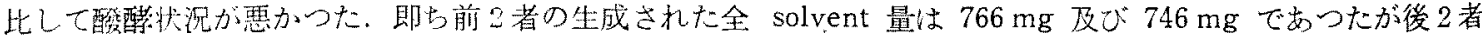
のそれは $1060 \mathrm{mg}$ 及び $1033 \mathrm{mg}$ であつた。

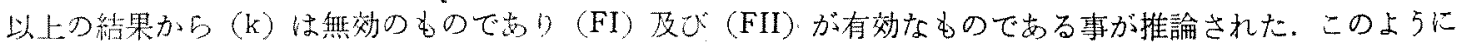

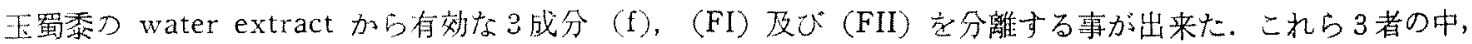
ての抽出の渦程から考えて見ても，又実測の結果も（f）が最も多量の無機物を含んでいた。 そこで（f）が有効

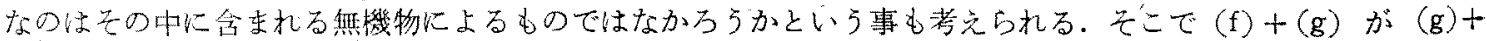


SPEAKMAN salts よりもずつと有効であつたのは，(f) 中に SPEAKMAN salts（この組成は $\mathrm{KH}_{2} \mathrm{PO}_{4} 0.05 \%$ ， $\mathrm{K}_{2} \mathrm{HPO}_{4} 0.05 \%, \mathrm{MgSO}_{4} \cdot 7 \mathrm{H}_{2} \mathrm{O} 0.02 \%, \mathrm{MnSO}_{4} \cdot 7 \mathrm{H}_{2} \mathrm{O} 0.001 \%, \mathrm{FeSO}_{4} \cdot 7 \mathrm{H}_{2} \mathrm{O} 0.001 \%, \mathrm{NaCl} 0.001 \%$ 分 0 組 成以外の無機物が存し，それが有効に倒いているためではないかと考えられる。そこで(f)の代りに（f）の ash

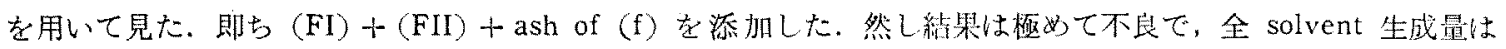
$394 \mathrm{mg}$ にすぎなかつた。(f) の分析結果は次の如くである。
(A) 水分 $13.0 \%$;
(B) 乍分 $15.1 \%$
(i) Cation (硫化水秦法)

第 1 属 $(\mathrm{Ag}, \mathrm{Hg}, \mathrm{Pb}) \cdots$ negative

第 2 属 $(\mathrm{Hg}, \mathrm{Pb}, \mathrm{Bi}, \mathrm{Cu}, \mathrm{Cd}, \mathrm{As}, \mathrm{Sb}$,

$\mathrm{Sn}) \cdots$ negative

第 3 属 $(\mathrm{Ni}, \mathrm{Co}, \mathrm{Fe}, \mathrm{Zn}, \mathrm{Mn}, \mathrm{Al}, \mathrm{Cr})$
第 4 属 $(\mathrm{Ba}, \mathrm{Sr}, \mathrm{Ca}) \cdots$ negative

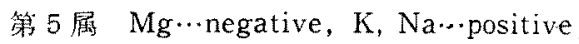
(ii) Anion

これは主として燐酸で，少量の硅 酸が混在.

(C) 全糖 (glucose として) 56.9\%.

この中還元糖 $3.9 \%$.

\section{‥negative}

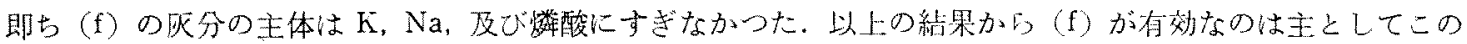
中に含まれる生長索によるものと推察される。但し（FI）及び（FII）の及老醌酸処理玉蜀禁に添加した場合恃全

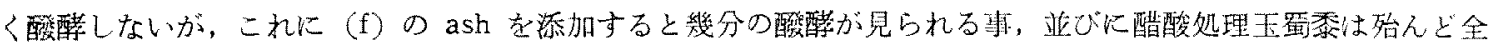

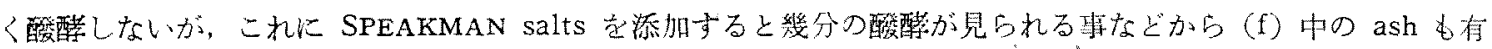
效に作用している事が判る。

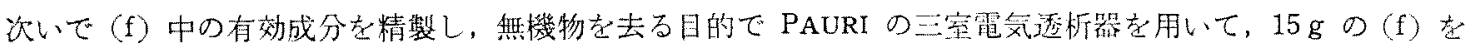

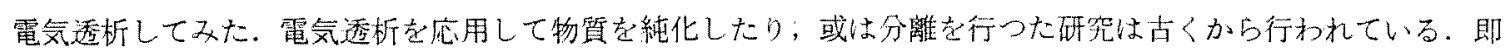

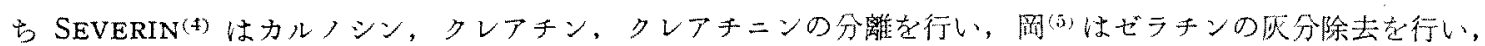
高橋, 白浜 ${ }^{(6)}$ は寒天についてこれを行つた。 又 FOSTER 等( ${ }^{(7)}$ は FOSTER の電析装置の中室に蛋白分解液を入

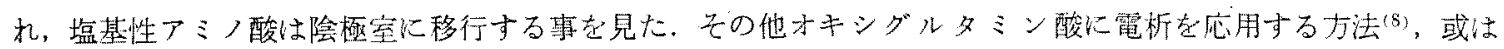

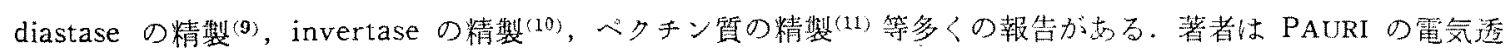
析器を用いて $15 \mathrm{~g}$ の（f） 200-cc の水に溶解して電析芏行つた，陰極膜にはコロジオン膜，陽極膜には絹布 にクロームゼラキンを染布した膜を用いた，両極䇪の液を透析完了李で時時蒸溜水で更新し，陽極室のものは

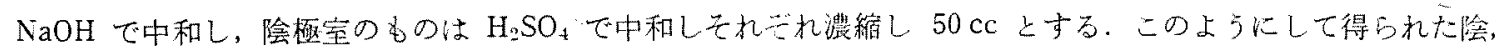

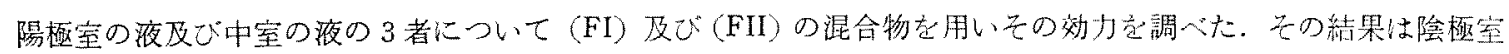

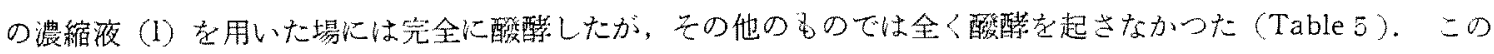
事から（f）の有効成分は陰極室に移行した事が判る。とこちが（1）の中にはカチオン(この場合は主とした K、Na）が移行した事は明らかであるから（1）の効果が果してこのもののみの影響か否か定知るために（1の

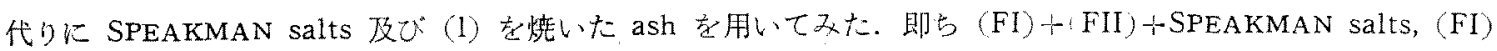

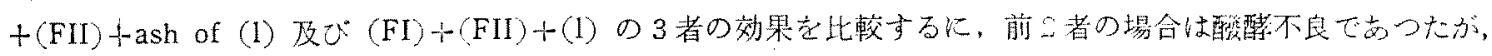
後者は前と闰じく酸酵完全であつた (Table 5 ).

この事から（1）の有効なのは無機物のみによるものでなく，主としてこの中の生育因子による事が明らかであ

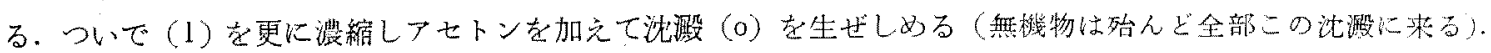

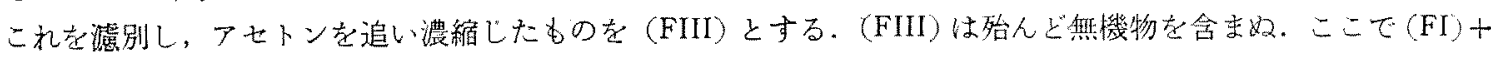

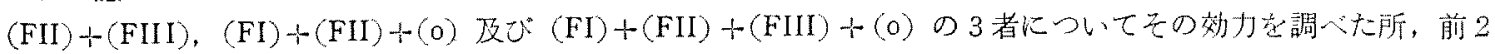

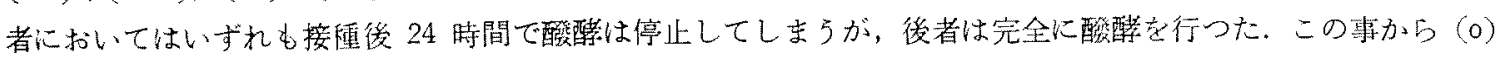
の重要性が一応考えられたが，(0) の代りに SPEAKMAN salts を用いた埸合即ち(FI) +(FII) +(FII) +

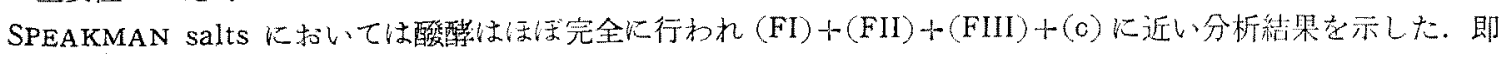
ち（）の効果は全く無機物（主として硫酸加里）によるむのである事が判明した（Table 5). 以上の如くにし て (FI)，(FII)，及び (FIII) なる有効成分を分別濃縮する事が出来た。これらの中 (FI) 及び (FIII)は殆んど 無機物を含九でいないが（FII）は多量つ ash（24.5\%，主体はカルシゥム）を含九でいた。然しこの（FII）の

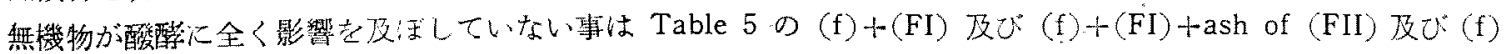


†(FI)+(FII) の分析結果る見れば明白である。

\section{III. 要 約}

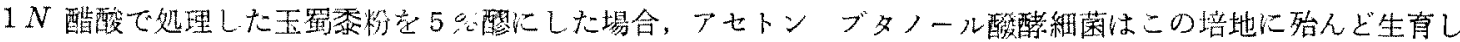

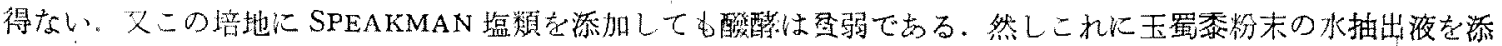

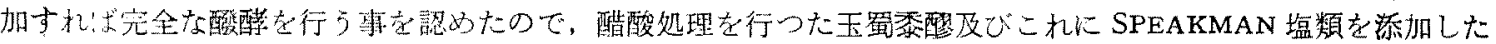
必の基本培地として用い，玉凅禁粉末水抽出液中の生有因子定追求し有效なるつのフラタションに分けた。

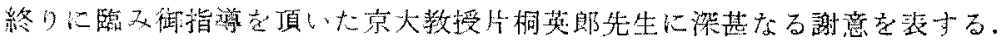
(1) 今井
跤化, 29, 523 (1955)。
(2) 今井 農化, 29，445 (1955).
(3) SPEAKMAN, H.B. : J. Biol. Chem., 58, 396 (1923)
(4) Severin, S.E. Z. physiol. Chem., 230, 109 (1934).
(5) 阔：工化, 1927, 396.
(6) 高標, 白浜：農化, 8, 1259 (1932).
(7) Foster, G.L., and SchMidT, C.L.A.

J. Biol. Chem., 56, 545 (1923).

(8) Gulland, J.M., and MoRris, C.J.O. : J. Chem. Soc., 1934, 1644.

(9) FRICKE, R., und KAJA, P. Ber., 57,310 (1924).

(10) 武富 工化, 1938，420.

(11) EMETT, A. M. : Biochem. J., 20, 564 (1926).

\section{Summary}

It was found that acetone-butanol fermentation bacteria could not grow on the mash from which ground maize was extracted with $1 N$ acetic acid. But when the water extract of maize was added to this medium it grew vigorously.

And using this acetic acid treated maize mash or salts added mash as standard the author traced the growth factors in the water extract of maize, and fractionated them into three fractions.

\section{アセトン ブタノール䣹酵細菌によるビタミン $\mathrm{B}_{2}$ の合成（第 5 報） ビオチンの効果及び純合成培地の設定 \\ 今 并和 民 (京都大学啀学部) \\ 昭和 30 年 3 月 4 日受理}

On the Formation of Riboflavin by Acetone-Butancl Fermentation Bacteria. Part 5 .

Effect of Biotin and Selting Up of Absolute Synthetic Medium.

By Eazutami IMAl (Faculty of Agriculture, Univ. of Kyoto)

\section{I. 緒 言}

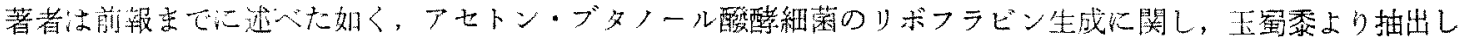

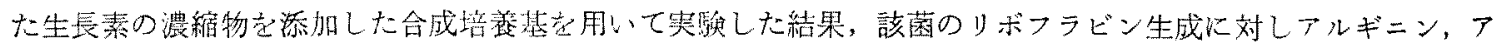
スバラギン及び phytic acid の他にもいつ重要な物質が必要である事を推論した。本報に於いてはこの物質がビ オチンでちる事老見出し，而もリボフラビンを多量に生成し得る純合成培地を設定する事が出来たのでここに報 告す。.

\section{II. 実 験 の 部}

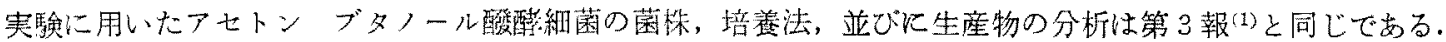
第3 報に述べた如く目的とする物質がアミ，酸ではあるまいとの結論を得たので，次微量で有効な或る生長素 ではなかるらかと考沈た。次の組成を有する基本培地炕ビオチン $1.2 \gamma / 100 \mathrm{cc}$, ビタミン $\mathrm{B}_{1}$ 塭酸塩 $200 \gamma / 100$

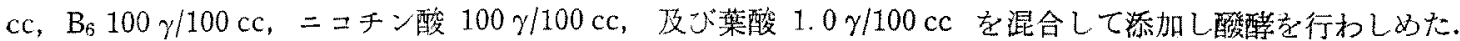

(培地組成) glucose 3\%, arginine- $\mathrm{HCl} 0.015 \%$, asparagine $0.15 \%$, phytic acid $0.016 \%, \mathrm{KH}_{2} \mathrm{PO}_{4} 0.05$ $\%, \mathrm{~K}_{2} \mathrm{HPO}_{4} 0.05 \%, \mathrm{MgSO}_{4} \cdot 7 \mathrm{H}_{2} \mathrm{O} 0.02 \%, \mathrm{MnSO}_{4} \cdot 7 \mathrm{H}_{2} \mathrm{O} 0.001 \%, \mathrm{NaCl} 0.001 \%, \mathrm{CaCO}_{3} 1.5 \%, \mathrm{FI}$, II, III $1 / 2$ 濃度（第 3 報(1)参照)。 